\title{
AgRICULTURAL WASTE MATERIALS AS COMPONENT OF ORGANIC POTTING MEDIA FOR THE ENDANGERED NEPENTHES TRUNCATA MACF. (PHILIPPINE PITCHER PLANT)
}

\begin{abstract}
Cyrose Suzie C. Silvosa • Eufemio T. Rasco Jr. $\bullet$ Mary Ann D. Maquilan •D epartment of B iological Sciences and Environmental Studies $\bullet$ College of Science and $M$ athematics $\bullet U$ niversity of the Philippines M indanao • M intal, 8022 D avao City • Philippines • Cs_silvosa@ yahoo.com
\end{abstract}

Keywords: Charcoaled rice husk, coconut coir dust, coconut fiber, chemical and physical characterization, Sphagnum moss, Nepenthes truncata.

A bstract: A gricultural waste materials, namely, coconut fiber (CF), coir dust (CD), and charcoaled rice husk ( $\mathrm{CRH}$ ) taken singly or in combination with commonly used organic substrates wood charcoal chips (WCC), chopped tree fern (CTF), sphagnum moss (SM), and osmunda fiber (OF) were characterized for their suitability as components of mixed potting media for Nepenthes truncata (M acf.) plantlets. Several mixed media were evaluated, each with a component for aeration (WCC, $\mathrm{CTF}$, or $\mathrm{CRH}$ ), moisture retention (CF, CD or SM ), and drainage (OF). Conventionally used container media mixes served as controls. Based on survival and leaf condition of plantlets, $C D$ could replace $S M$, and both were superior to $C F$ in moisture retention, while $C R H$ was superior to wood charcoal chips and tree fern for aeration. Both CD and CRH are locally available and inexpensive compared to the materials they could replace. Small-sized plantlets performed better in Treatment 6 (T6) (2:1:1 mixture of SM, OF, and CRH) and Control 1 (pure SM ) while medium-sized plantlets only preferred $\mathrm{T} 6$. Physico-chemical properties of $\mathrm{T} 6$ suggest that the appropriate medium for $\mathrm{N}$. truncata plantlets is slightly acidic with low electrical conductivity, high porosity, moderate water holding capacity, and moderate water retention efficiency.

\section{Introduction}

Nepenthes truncata is an endemic plant of the Philippines, particularly in M indanao ( $M$ cPherson \& A moroso 2011). It is now considered as a commercially valuable ornamental but is classified as endangered by the IUCN (Clarke et al. 2006) due to slash and burn farming methods, over-collection from the wild, and poor cultivation practices of other crops such as vegetables and ornamentals. A suitable artificial media for cultivation of $\mathrm{N}$. truncata will contribute to a technology package for propagated plantlets and reduce plant collection from the wild. All Nepenthes species naturally grow in low-nutrient habitats such as peat swamp, mountain rainforests, and pure sand (H orman 2000). In nurseries, soilless mixes composed purely of organic substances are commonly used as growing media ( $G$ reer 1998). In previous studies on cultivation of Nepenthes species, the growing media recommended were long fiber sphagnum moss (Butler 1990), a combination of osmunda fiber and sphagnum moss (De Kanel \& Smith 1992), and perlite in combination with long fiber sphagnum moss and peat moss (Rice 2006).

Waste products are now being utilized as components in plant growing media. A mong these, pruning waste compost (PWC) (H ernández-A paolaza et al. 2005) and 7:3 peat-rice husk mixture (M arianthi 2006) have been used for pines, PWC plus spent mushroom compost (SMC) for orna- 
mental plants (B enito et al. 2005), and compost from biosolids combined with yard trimmings for Pachystachys lutea Nees (Wilson \& Stofella 2000). Coconut fiber and coir dust have been used as substitutes for peat in many studies (A bad et al. 2002; N oguera et al. 2000; W ilson \& Stofella 2000) due to properties similar to peat (Lennartson 1997). H owever, the suitability of coconut fiber or coir dust as growing media for epiphytic Nepenthes species has not yet been explored. Reuse of waste materials as alternative to other organic container substrates can help lessen the need for extracting resources from natural habitats, lessen residue accumulation in the environment (Raviv et al. 1986) and cut down the cost of growing media (Ingelmo et al. 1998). The study was conducted to test the suitability of agricultural waste materials ( $C F, C D$, and $C R H)$ in combination with locally available organic substrates (SM , OF, CTF, or W CC) for growing N. truncata in the nursery.

\section{$M$ aterials and $M$ ethods}

Physico-chemical characterization of media and their components. The mixed media as well as their components were characterized with three replicates per test. Determination of the waterholding capacity was done through a modification (use of hanging pot instead of a clay pot) of the procedure described by Holcomb (2004). For porosity (total and aeration) characteristics, a modification (use of hanging basket lined with plastic sheet instead of clay pot) of the procedure in the N ursery Production Factsheet by M AFF (2001) was followed. Water-retention efficiency of the potting mixes was determined by adopting the procedure of $\mathrm{N}$ ursery and $\mathrm{G}$ arden Industry A ustralia (2002). Electrical Conductivity (EC) and pH characterization was done by the Department of A griculture, Davao City using 1:2 extraction method (A rgo 2004).

Plant M aterial. Plantlets of N. truncata, collected from the wild and maintained for 3 months in a uniform medium of sphagnum moss at the Fuertes N ursery in M arilog District, Davao City, were used in the experiments (Fig. 1). Two arbitrary size categories were evaluated in the experi-
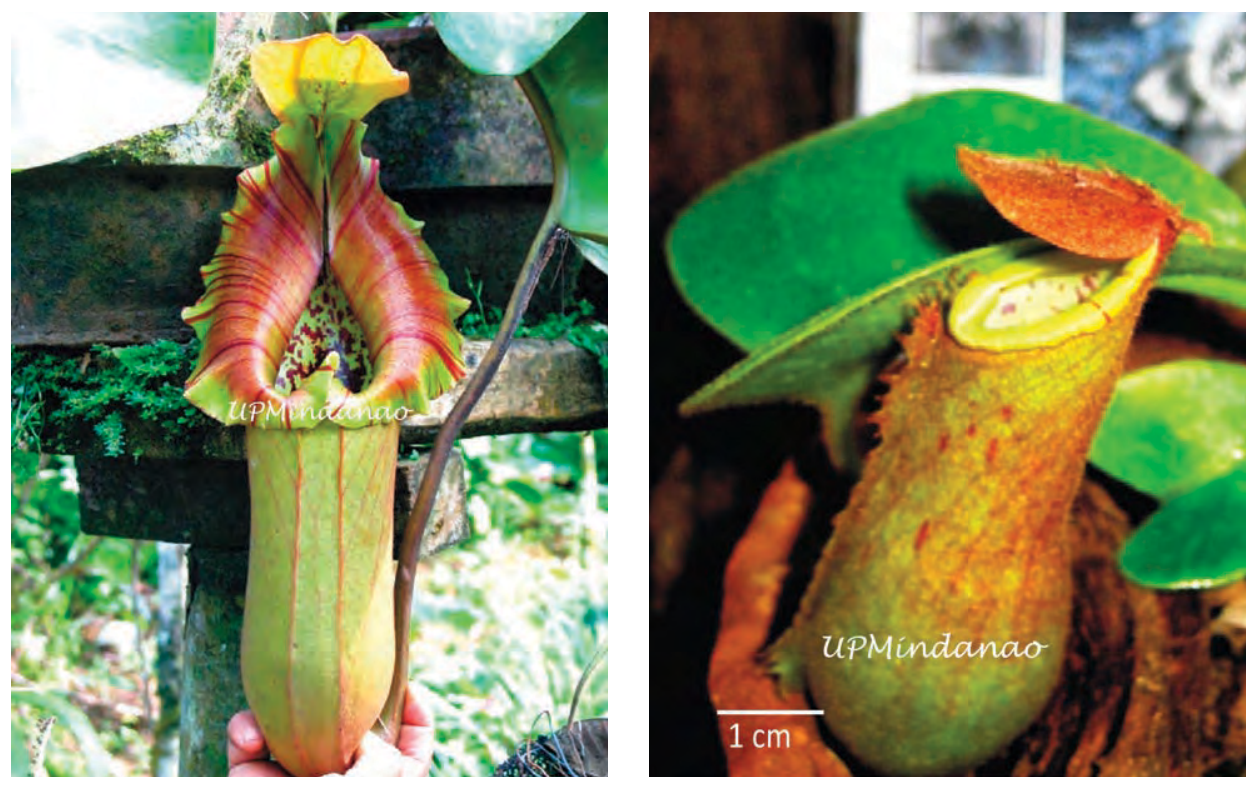

Figure 1: Nepenthes truncata mother plant (left) and representative plantlet used in the experiment (right). 


\begin{tabular}{|c|c|c|c|c|}
\hline \multirow[t]{3}{*}{ Treatment } & \multicolumn{4}{|c|}{ Components ( $\%$ by volume) } \\
\hline & \multirow{2}{*}{$\frac{\text { A eration }(25)}{\text { Experiments } 1 \& 2}$} & \multicolumn{2}{|c|}{ M oisture retention (50) } & \multirow{2}{*}{$\begin{array}{c}\text { Drainage (25) } \\
\text { Experiments } 1 \& 2\end{array}$} \\
\hline & & Experiment 1 & Experiment 2 & \\
\hline 1 & WCC & $\mathrm{CF}$ & $C D$ & OF \\
\hline 2 & CTF & $\mathrm{CF}$ & $C D$ & OF \\
\hline 3 & $\mathrm{CRH}$ & $\mathrm{CF}$ & $C D$ & OF \\
\hline 4 & WCC & SM & SM & OF \\
\hline 5 & CTF & SM & SM & OF \\
\hline 6 & $\mathrm{CRH}$ & SM & SM & OF \\
\hline
\end{tabular}

CF-coconut fiber; OF- osmunda fiber; WCC- wood charcoal chips; CTF- chopped tree fern root; CRHcharcoaled rice husk; SM - sphagnum moss

Table 2. Percentage of survival ${ }^{1}$ of Nepenthes truncata Macf. plantlets in different potting mixes from January to July 2005.

\begin{tabular}{|l|c|c|r|r|r|r|r|}
\hline \multirow{2}{*}{ Code } & \multirow{2}{*}{ Potting mix } & \multicolumn{5}{|c|}{ M ean \% Survival of plantlets at specified interval (days) } \\
\cline { 3 - 8 } & & 30 & 60 & $90^{3}$ & 120 & 150 & 180 \\
\hline C1 & Control 1 & 100 & 100 & $100 \mathrm{a}$ & 100 & 100 & 100 \\
\hline C2 & Control 2 & 100 & 90 & $90 \mathrm{ab}$ & 90 & 90 & 90 \\
\hline C3 & Control 3 & 100 & 100 & $90 \mathrm{ab}$ & 80 & 70 & 50 \\
\hline C4 & Control 4 & 90 & 80 & $70 \mathrm{ab}$ & 60 & 50 & 40 \\
\hline T1 & CF-OF-WCC & 100 & 70 & $60 \mathrm{~b}$ & 30 & 10 & 10 \\
\hline T2 & CF-OF-CTF & 100 & 80 & $80 \mathrm{ab}$ & 30 & 30 & 20 \\
\hline T3 & CF-OF-CRH & 100 & 100 & $100 \mathrm{a}$ & 80 & 80 & 70 \\
\hline T4 & SM-OF-WCC & 100 & 100 & $90 \mathrm{ab}$ & 80 & 80 & 80 \\
\hline T5 & SM-OF-CTF & 100 & 90 & $70 \mathrm{ab}$ & 60 & 60 & 60 \\
\hline T6 & SM-OF-CRH & 100 & 100 & $100 \mathrm{a}$ & 100 & 100 & 100 \\
\hline GRA ND M EAN & & 99 & 91 & 85 & 71 & 67 & 62 \\
\hline $\begin{array}{l}\text { P value (potting } \\
\text { mix } \times \text { plant size) }\end{array}$ & & 0.447 & 0.070 & 0.016 & 0.090 & 0.216 & 0.113 \\
\hline
\end{tabular}

${ }^{1}$ data were transformed using square-root transformation

2 means within columns without letters are not significantly different at al pha $=0.05$

${ }^{3}$ means with common letter(s) are not significantly different using DM RT at al pha $=0.05$.

Control 1: $100 \%$ long fiber sphagnum moss;

Control 2: $50 \%$ peat moss, $25 \%$ perlite, and $25 \%$ pine tree bark;

Control 3: $33.33 \%$ river pebbles, $33.33 \%$ tree fern root, and $33.33 \%$ wood charcoal;

Control $4: 66.67 \%$ sphagnum moss, and $33.33 \%$ tree fern root

CF : $50 \%$ coconut fiber; OF-25\% osmunda fiber; W CC - $25 \%$ wood charcoal chips; CTF- $25 \%$ chopped tree fern root; $\mathrm{CRH}-25 \%$ charcoaled rice husk; SM - $50 \%$ sphagnum moss 


\begin{tabular}{|c|c|c|c|c|c|c|c|c|}
\hline \multirow[t]{2}{*}{ Plantlet size } & \multirow[t]{2}{*}{ Potting mix } & \multirow[t]{2}{*}{ Code } & \multicolumn{6}{|c|}{$\%$ Survival of plantlets at specified interval (days) ${ }^{2}$} \\
\hline & & & 30 & 60 & $90^{3}$ & $120^{3}$ & $150^{3}$ & $180^{3}$ \\
\hline \multirow[t]{10}{*}{ Small } & Control 1 & $\mathrm{C} 1$ & 100 & 100 & $100 a$ & $100 a$ & $100 a$ & $100 a$ \\
\hline & Control 2 & $\mathrm{C} 2$ & 100 & 80 & $80 a b$ & $80 a b$ & $80 a b$ & $80 a$ \\
\hline & Control 3 & C3 & 100 & 100 & $100 \mathrm{a}$ & $80 a b$ & $80 a b$ & $60 a b$ \\
\hline & Control 4 & $\mathrm{C} 4$ & 80 & 60 & $40 \mathrm{bc}$ & $40 \mathrm{bc}$ & $40 \mathrm{bc}$ & $20 \mathrm{bc}$ \\
\hline & CF-OF-WCC & T1 & 100 & 40 & $20 c$ & $0 c$ & $0 c$ & $0 c$ \\
\hline & CF-OF-CTF & $\mathrm{T} 2$ & 100 & 60 & $60 a b c$ & $0 c$ & $0 c$ & $0 c$ \\
\hline & CF-OF-CRH & T3 & 100 & 100 & $100 a$ & $100 a$ & $100 a$ & $100 a$ \\
\hline & SM-OF-WCC & $\mathrm{T} 4$ & 100 & 100 & $80 a b$ & $60 a b$ & $60 a b$ & $60 a b$ \\
\hline & SM-OF-CTF & T5 & 100 & 80 & $60 a b c$ & $60 \mathrm{ab}$ & $60 \mathrm{ab}$ & $60 \mathrm{ab}$ \\
\hline & SM-OF-CRH & T6 & 100 & 100 & $100 a$ & $100 a$ & $100 a$ & $100 a$ \\
\hline M ean & & & 98 & 82 & 74 & 62 & 62 & 58 \\
\hline $\begin{array}{l}\text { P value (across } \\
\text { potting mixes) }\end{array}$ & & & 0.456 & 0.086 & 0.015 & 0.000 & 0.000 & 0.000 \\
\hline \multirow[t]{10}{*}{ M edium } & Control 1 & $\mathrm{C} 1$ & 100 & 100 & 100 & 100 & $100 a$ & $100 a$ \\
\hline & Control 2 & $\mathrm{C} 2$ & 100 & 100 & 100 & 100 & $100 a$ & $100 a$ \\
\hline & Control 3 & C3 & 100 & 100 & 80 & 80 & $60 a b$ & $40 a b$ \\
\hline & Control 4 & $\mathrm{C} 4$ & 100 & 100 & 100 & 80 & $60 a b$ & $60 a b$ \\
\hline & CF-OF-WCC & T1 & 100 & 100 & 100 & 60 & $20 \mathrm{~b}$ & $20 \mathrm{~b}$ \\
\hline & CF-OF-CTF & $\mathrm{T} 2$ & 100 & 100 & 100 & 60 & $60 \mathrm{ab}$ & $40 a b$ \\
\hline & CF-OF-CRH & T3 & 100 & 100 & 100 & 60 & $60 a b$ & $40 a b$ \\
\hline & SM-OF-WCC & $\mathrm{T} 4$ & 100 & 100 & 100 & 100 & 100a & $100 a$ \\
\hline & SM-OF-CTF & T5 & 100 & 100 & 80 & 60 & $60 a b$ & $60 a b$ \\
\hline & SM-OF-CRH & T6 & 100 & 100 & 100 & 100 & $100 a$ & $100 a$ \\
\hline M ean & & & 100 & 100 & 96 & 80 & 72 & 66 \\
\hline $\begin{array}{l}P \text { value (across } \\
\text { potting mixes) }\end{array}$ & & & \multicolumn{2}{|c|}{$\begin{array}{l}\text { No Value (subsets } \\
\text { cannot be } \\
\text { computed with } \\
\text { alpha }=0.05 \text { ) }\end{array}$} & 0.543 & 377 & 0.048 & 0.010 \\
\hline
\end{tabular}

${ }^{1}$ data were transformed using square-root transformation

${ }^{2}$ means within columns without letters are not significantly different at al pha $=0.05$

${ }^{3}$ means within columns with common letter(s) are not significantly different using DM RT at alpha $=0.05$.

Control 1: $100 \%$ long fiber sphagnum moss;

Control 2: $50 \%$ peat moss, $25 \%$ perlite, and $25 \%$ pine tree bark;

Control 3: $33.33 \%$ river pebbles, $33.33 \%$ tree fern root, and $33.33 \%$ wood charcoal;

Control 4: $66.67 \%$ sphagnum moss, and $33.33 \%$ tree fern root

CF : $50 \%$ coconut fiber; OF-25\% osmunda fiber; W CC - $25 \%$ wood charcoal chips; CTF- $25 \%$ chopped tree fern root; $\mathrm{CRH}-25 \%$ charcoaled rice husk; SM - 50\% sphagnum moss 
ments: small and medium. Small plantlets have internode length (IL ) $\leq 1 \mathrm{~cm}$ with at least 6 nodes while medium plantlets have either IL $<1 \mathrm{~cm}$ with at least 9 nodes or with $\mathrm{IL}>1 \mathrm{~cm}$ with at least 4 nodes.

Experimental conditions for evaluation of nursery media. The experiments were conducted at a nursery in M arilog District, Davao City with a site elevation of $1200 \mathrm{~m}$ and a temperature range of 18 to $27^{\circ} \mathrm{C}$. Light intensity ranged from 2200 to 18480 Iux (SPER SCIENTIFIC 840020 digital light meter). Experiment 1 was conducted during the dry season (J anuary to J uly 2005) with relative humidity range of 50.2 to $84.6 \%$ (V M R Traceable ${ }^{\circledR}$ Hygrometer), and average monthly rainfall of $101.57 \mathrm{~mm}$ as measured by the Philippine A tmospheric, Geophysical and A stronomical Services A dministration (PAGASA) in L anang, Davao City. Experiment 2 was conducted during the wet season (A ugust to December 2005) with relative humidity range of 60.8 to $85.6 \%$ and average monthly rainfall of $155.52 \mathrm{~mm}$.

Fertilizer application and watering. A II plantlets were sprayed monthly with commercial foliage orchid fertilizer (M anusol ${ }^{\circledR}$ ), with an NPK ratio of 19:19:19 and $\mathrm{M} \mathrm{g}, \mathrm{Cu}, \mathrm{Mn}, \mathrm{Zn}$ micronutrients. Each formulation contained two tablespoons (about $30 \mathrm{~g}$ ) of the fertilizer dissolved in $48 \mathrm{~L}$ of rainwater to obtain a concentration that was only one-third of the ordinary dosage for orchids to prevent over fertilization of the plantlets. Watering was done daily except during rainy days. Either spring water or stored rainwater was used and application was done using a hand-held atomizer.

Pest and fungi control. All plantlets were sprayed monthly with insecticide and fungicide using commercial organophosphate insecticide, profenofos (Selecron ${ }^{\circledR}$ ), a systemic fungicide, metalaxyl-m (Ridomil ${ }^{\circledR}$ ), and a broad-spectrum fungicide, mancozeb (Dithane ${ }^{\circledR}$ ). Individual solutions of the chemicals were initially prepared prior to preparation of the spray solution as follows: Insecticide solution was prepared by mixing $1 \mathrm{ml}$ profenofos ( $0.5 \mathrm{~g} \cdot \mathrm{L}^{-1}$ active ingredient) to $1 \mathrm{~L}$ rainwater; systemic fungicide solution consisted of $3.9 \mathrm{~g}$ metalaxyl-m (0.0098 $\mathrm{g} \cdot \mathrm{L}^{-1}$ active ingredient) added to $1 \mathrm{~L}$ rainwater; and broad-spectrum fungicide solution consisted of $1 \mathrm{~g}$ mancozeb $\left(1.6 \mathrm{~g} \cdot \mathrm{L}^{-1} \mathrm{ac}\right.$ tive ingredient) to $1 \mathrm{~L}$ of rainwater. All solutions were thoroughly mixed and transferred to individual plastic bottles. To prepare the spray solution, $500 \mathrm{ml}$ of each chemical solution was mixed. A spreader sticker (Hoestick ${ }^{\circledR}$ ) was added to the pesticide and fungicide mixture at a concentration of $0.53 \mathrm{ml} \mathrm{L}-1$, to allow even distribution of the chemicals on the plant's surface. The insecticidefungicide-sticker mixture was applied to the plantlets using a plastic hand-held atomizer.

Experiment 1: U se of coconut fiber as organic medium component. There were separate setups for small and medium plantlets, each laid out in a Completely Randomized D esign (CRD) with four controls (commercial potting mixes), six experimental treatments, and five replicates, with one plant per replicate. The control treatments were: (C1) long fiber SM (C atalani 2000); (C2) 2:1:1 mixture of peat moss, perlite, and pine tree bark (Sarracenia N orthwest 2012; Bilderback 2002); (C3) 1:1:1 mixture of river pebbles, tree fern root, and WCC (Vogelpoel 1980; M alesiana Tropicals n.d.); and (C4) 2:1 mixture of SM and CTF tree fern root (M alesiana Tropicals n.d.). The compositions of the experimental potting media are shown in Table 1. Survival and condition of the plantlets were monitored monthly for five months.

Experiment 2: Use of coconut coir dust as organic medium component. Due to high mortality rates observed in potting mixes with CF in Experiment 1, CF was replaced with CD (Table 2), which has physico-chemical properties comparable to SM (Cresswell 2001), in Experiment 2. The same four controls used in Experiment 1 were also used in Experiment 2, thus the total number of treatments in a single-factor analysis was 10 . To determine the contributions of various components to the plant response, the 6 experimental media were also analyzed as $2 \times 2 \times 3$ factorial experiment, where the factors were plant size (small or medium), component for moisture-retention (CD 
or SM ), and component for aeration (WCC, CTF, or CRH), respectively. As in Experiment 1, the component for drainage (OF) was held constant. Survival and condition of the plantlets were monitored monthly for five months. The condition of the leaves and pitchers were evaluated using a 1 to 5 rating scale where 1 is least and 5 is best.

Data Analyses. Statistical analyses were done using A nalysis of Variance (ANOVA) of a CRD and mean separation was done using DMRT. Pearson's Correlation A nalysis was used to test for correlation between physical properties of potting mixes. For the percentage survival, data was transformed using square-root transformation.

\section{Results and Discussion}

Experiment 1: U se of coconut fiber as organic medium component.

The experiment suffered from moisture stress due to lack of rain and ineffective manual watering. A t 60 days, there was a marked reduction in survival in some treatments; and in 90 days, there were statistically significant differences. $\mathrm{C} 1$ and $\mathrm{T} 6$ gave the highest and most consistent survival rates while $\mathrm{T} 1$ gave the lowest (Table 2 ).

The survival rates of small plantlets were lower than that of medium plantlets (Table 3). Severe symptoms of water stress such as yellowing of leaves and curling of leaf blades accompanied low survival rates. No new shoots were produced and lower leaves tend to undergo abscission.

Plantlets grown in coconut fiber-based mixes have respectively lower survival rates of $46.7 \%$ $(p=0.007), 40 \%(p=0.001)$, and $33.3 \%(p=0.00)$ for 120,150 , and 180 days after transfer compared to a consistent $80 \%$ survival rate for plantlets grown in media with sphagnum moss.

\section{Experiment 2: Use of coconut coir dust as organic medium component}

A $100 \%$ survival after 150 days of observation was obtained in all potting mixes in contrast to the varied survival rates of the plantl ets in Experiment 1 . This is not only due to the use of CD instead of CF in the growing medium but also due to higher amount of rainfall when Experiment 2 was conducted. There was no significant difference among the controls ( $C 1$ to $C 4$ ) in terms of leaf condition. However, among 6 experimental treatments, T1 with CD was inferior $(p=0.01)$ compared to potting mixes T3 with CD, T5, and T6. Treatments T5 and T6 were also significantly better in leaf condition $(p=0.01)$ than all 4 controls and the other experimental treatments. Of the three factors (plant size, component for moisture-retention, and component for retention) only plantlet size had a significant effect on the condition of N. truncata leaves. Throughout the experiment, the leaf condition of the small plantlets were significantly better than that of medium plantlets $(p=0.03)$. Coir dust and sphagnum moss were comparable, while rice husk was better than wood charcoal and tree fern among the components for aeration.

Physico-chemical characterization of organic substrates and potting mixes in relation to plant growth. A growing medium with EC readings bel ow the critical level of $2.0 \mathrm{mmhos}^{\circ} \mathrm{cm}^{-1}$ is considered a good substrate for the plant (A \& L Plains A gricultural Lab, Inc. 2001; A rgo 2004; Harris Laboratories 2009). Other suitable physico-chemical properties include: $\mathrm{pH}$ between 6.5 and 7.0 but some species have developed adaptations that allow them to thrive at a higher (M auseth 1998)

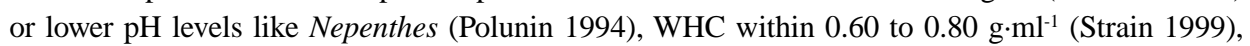
WRE values greater than $80 \%$ (N GIA 2002), A P of at least 20 to $25 \%$ and as high as $45 \%$ in warmer temperatures with TP that must be greater than 60 to $70 \%$ (M A FF 2001). B ased on physico-chemical analyses, the EC indicate that all the potting substrates and potting mixes are suitable. Since N. truncata plantlets prefer a slightly acidic medium (Polunin 1994), the majority of the mixes are found suitable except T 1 with CF, T4, and C3, which are basic. W HC and W RE were highly correlated and 


\begin{tabular}{|c|c|c|c|c|c|c|c|}
\hline \multirow[t]{2}{*}{ Potting M ixes } & \multirow[t]{2}{*}{ Code } & \multicolumn{6}{|c|}{ Physico-Chemical Properties ${ }^{1}$} \\
\hline & & AP & TP & WHC & WRE & $\mathrm{EC}$ & $\mathrm{pH}$ \\
\hline \multicolumn{8}{|c|}{ Control Treatments } \\
\hline Control 1 & $\mathrm{C} 1$ & $61.02 a$ & $75.23 a$ & $0.26 f$ & $25.70 \mathrm{bcd}$ & 0.72 & 6.6 \\
\hline Control 2 & $\mathrm{C} 2$ & $38.09 a$ & $59.17 a$ & $0.45 c$ & $16.70 \mathrm{e}$ & 0.33 & 5.1 \\
\hline Control 3 & C3 & $42.13 a$ & $60.39 a$ & $0.02 \mathrm{~h}$ & 20.00de & 0.24 & 7.8 \\
\hline Control 4 & $\mathrm{C} 4$ & $52.59 a$ & $63.94 a$ & $0.32 d$ & $1.33 f$ & 0.63 & 6.6 \\
\hline \multicolumn{8}{|c|}{ Experimental Treatments } \\
\hline CF-OF-WCC & T1 with CF & $52.79 a$ & $69.68 a$ & $0.06 \mathrm{e}$ & $2.33 \mathrm{e}$ & 0.51 & 8.4 \\
\hline CF-OF-CTF & T2 with CF & $49.53 a$ & $63.46 a$ & $0.03 e$ & $4.33 \mathrm{e}$ & 0.27 & 6.0 \\
\hline CF-OF-CRH & T3 with CF & $43.26 a$ & $61.16 a$ & $0.17 d$ & $11.00 \mathrm{~d}$ & 1.15 & 5.3 \\
\hline CD-OF-WCC & $\mathrm{T} 1$ with $\mathrm{CD}$ & $40.23 b c$ & $53.67 b$ & $0.46 c$ & $30.00 \mathrm{ab}$ & 0.44 & 6.8 \\
\hline CD-OF-CTF & T2 with $C D$ & $42.23 a b c$ & $48.92 b$ & $0.67 a$ & $28.30 \mathrm{abc}$ & 0.32 & 6.6 \\
\hline CD-OF-CRH & T3 with $C D$ & $41.14 b c$ & $42.96 b$ & $0.63 \mathrm{bc}$ & $32.30 \mathrm{a}$ & 0.31 & 6.2 \\
\hline SM-OF-WCC & T4 & $60.03 a$ & $80.62 a$ & $0.21 \mathrm{~g}$ & $27.30 a b c$ & 0.60 & 7.8 \\
\hline SM-OF-CTF & T5 & $52.16 a$ & $63.26 a$ & $0.28 \mathrm{ef}$ & $16.00 \mathrm{e}$ & 1.02 & 6.7 \\
\hline SM-OF-CRH & T6 & $61.58 a$ & $77.72 \mathrm{a}$ & $0.29 \mathrm{de}$ & $23.30 \mathrm{~cd}$ & 0.85 & 6.0 \\
\hline M ean & & 48.98 & 67.46 & 0.36 & 22.10 & 0.57 & 6.6 \\
\hline$P$ value & & 0.03 & 0.03 & 0.00 & 0.00 & & \\
\hline $\begin{array}{l}\text { Coefficient of } \\
\text { Correlation }\end{array}$ & & \multicolumn{2}{|c|}{$0.00^{3}$} & \multicolumn{2}{|c|}{$0.00^{4}$} & & \\
\hline
\end{tabular}

${ }^{1}$ means within columns with common letter(s) or no letters are not significantly different using DM RT at al pha $=0.05$.

${ }^{2}$ correlated at 0.05 level

${ }^{3}$ correlation between AP and TP

${ }^{4}$ correlation between WHC and WRE

AP: aeration porosity (\%); TP- total porosity (\%); WHC- water-holding capacity $\left(\mathrm{g} \mathrm{ml}^{-1}\right)$; WRE- water-retention efficiency (\%); EC- electrical conductivity $\left(\mathrm{mmhos}^{\bullet} \mathrm{cm}^{-1}\right)$; Expt- Experiment Control 1: $100 \%$ long fiber sphagnum moss;

Control 2: $50 \%$ peat moss, $25 \%$ perlite, and $25 \%$ pine tree bark;

Control 3: $33.33 \%$ river pebbles, $33.33 \%$ tree fern root, and $33.33 \%$ wood charcoal;

Control 4: $66.67 \%$ sphagnum moss, and $33.33 \%$ tree fern root

CF : $50 \%$ coconut fiber; OF-25\% osmunda fiber; W CC - $25 \%$ wood charcoal chips; CTF- $25 \%$ chopped tree fern root; $\mathrm{CRH}-25 \%$ charcoaled rice husk; CD-50\% coconut coir dust; SM - 50\% sphagnum moss

only T 2 with $C D$ and T3 with CD fall within the required WHC range while the WRE for all mixes are less than $80 \%$ (unsuitable). For porosity characteristics, A P and TP were found to be highly correlated. AP readings for all mixes were above 20 to $25 \%$ (suitable) while TP readings of all mixes except $C 2$ and $T 1$ with $C D, T 2$ with $C D$, and T3 with $C D$ are greater than the standard $60 \%$. Potting 
Table 5. Physico-chemical properties of individual organic substrates for plantlets of Nepenthes truncata Macf.

\begin{tabular}{|l|c|c|c|}
\hline Substrates & $\begin{array}{c}\text { Water retention efficiency } \\
(\%)\end{array}$ & $\begin{array}{c}\text { Electrical conductivity (mmhos } \\
\left.\mathrm{cm}^{-1}\right)\end{array}$ & $\mathrm{pH}$ \\
\hline Coconut coir dust & $35.67 \mathrm{~b}$ & 0.27 & 7.1 \\
\hline Coconut fiber & $6.67 \mathrm{de}$ & 0.69 & 7.1 \\
\hline Charcoaled rice husk & $38.33 \mathrm{~b}$ & 1.01 & 5.7 \\
\hline Osmunda fiber & $2.67 \mathrm{e}$ & 1.43 & 6.4 \\
\hline Peat moss & $25.67 \mathrm{c}$ & 0.32 & 4.9 \\
\hline Perlite & $86.67 \mathrm{a}$ & 0.14 & 7.1 \\
\hline Pine bark chips & $88.67 \mathrm{a}$ & 0.59 & 5.2 \\
\hline River pebbles & $2.67 \mathrm{e}$ & 0.11 & 8.0 \\
\hline Sphagnum moss & $38.33 \mathrm{~b}$ & 0.96 & 6.8 \\
\hline Tree fern root & $1.00 \mathrm{e}$ & 0.34 & 5.5 \\
\hline Wood charcoal & $3.00 \mathrm{e}$ & 0.52 & 8.0 \\
\hline M ean & 29.94 & 0.58 & 6.53 \\
\hline P value & 0.00 & & \\
\hline
\end{tabular}

${ }^{1}$ means within column with common letter(s) or no letters are not significantly different using DM RT at alpha $=0.05$.

mixes with coconut coir dust tend to hold more water compared to the other mixes (Table 4).

A mong the components (Table 5), wood charcoal and river pebbles may be too basic and not ideal to be used while peat moss, tree fern, charcoaled rice husk, and pine bark chips are acidic and may be suitable. Thus, treatments with wood charcoal or river pebbles have lower rates of survival than most of those with acidic components in Experiment 1. In terms of WRE, pine bark chips and perlite are significantly better compared to other components (Table 5). Thus, C2 potting mix was favorable for the survival of the plantlets in Experiments 1 and 2.

It seems that the combination of acidic reaction and intermediate W RE from sphagnum moss and charcoaled rice husk make an ideal potting mix as shown by high survival rates of both small and medium plantlets of T6 (Tables 3, 4) in Experiment 1. B ased on physico-chemical properties, coir dust may be used as a substitute to sphagnum moss. H owever, beneficial microorganisms found in sphagnum moss that prevents root rot pathogens (Premier Press 2000), probably absent in coconut coir dust, may help in the establishment of $\mathrm{N}$. truncata plantlets.

\section{Conclusions}

The organic substrates coir dust (CD) and sphagnum moss (SM ) could be interchangeable, and both were superior to coconut fiber (CF) as a component for moisture retention, while charcoaled rice husk ( $\mathrm{CRH}$ ) was superior over wood charcoal chips (WCC) and chopped tree fern (CTF) as a component for aeration based on survival and leaf condition parameters. Both small and medium plantlets performed better in Treatment 6 (T6) (2:1:1 mixture of SM , OF, and CRH) and C1 (SM ). Leaf condition was found to be significantly better in Treatment 5 (2:1:1 mixture of SM, OF, and CTF) and T6 compared to other mixes while small plantlets have significantly better leaf condi- 
tion than medium plantlets. Physico-chemical properties of the superior treatment, T6, suggest that an appropriate medium for growing Nepenthes truncata should have the following characteristics: slightly acidic ( $\mathrm{pH}=6.8)$, moderate electrical conductivity $\left(0.85 \mathrm{mmhos}^{\circ} \mathrm{cm}^{-1}\right)$, high aeration porosity $(61.58 \%)$ and total porosity $(77.72 \%)$, and moderate water-holding capacity $\left(0.29 \mathrm{~g} \cdot \mathrm{mL}^{-1}\right)$ and water retention efficiency $(23.30 \%)$.

A cknowledgments: This study was supported by Philippine Council for A griculture, Forestry, and Natural Resources Research and Development (PCCARD), U niversity of the Philippines Research Grant and Department of A griculture, B ureau of Plant Industry.

\section{References}

A \& L Plains L aboratories, Inc. 2008. Soil analysis sample report with reference guide explanations. http://www.al-labs-plains.com/soil.html, accessed 6 February 2012.

A bad, M., N oguera, P., Puchades, R., M aquieira, A ., and N oguera, V. 2002. Physico-chemical and chemical properties of some coconut coir dusts for use as a peat substitute for containerised ornamental plants. Bioresour. Technol. 82(3): 241-245.

A rgo, B. 2004. Understanding pH management and plant nutrition. Jour. Internat. Phalaenopsis Alliance 13: 3.

B enito, M ., M asaguer, A ., De A ntonio, R., and M oliner, A. 2005. U se of pruning waste compost as a component in soilless growing media. Bioresour. Technol. 96(5): 597-603.

Bilderback, T. 2002. M anaging container substrates. N ursery crop science. http://www.ces.ncsu.edu/ depts/hort/nursery/cultural/cultural_docs/substrates/managing_container_subs.pdf, accessed 6 February 2012.

B utler, D.E. 1990 Nepenthes growing media. Carniv. PI. Newslett. 19(1-2): 29-31.

Catalani, M. 2000. Nepenthes truncata cultivation. Nepenthes University. http://www.cpjungle. com/nuctru.htm, accessed 6 February 2012.

Clarke, C.M ., Cantley, R., N erz, J., Rischer, H., and Witsuba, A. 2006. Nepenthes truncata. In: 2006 IU CN Red List of Threatened Species, IU CN 2006, Retrieved on 11 M ay 2006, Listed as Endangered (2000) (EN B 1+2d v2.3).

Cresswell, G. 2001. Coir dust a proven alternative to peat. Technical Report. 13 p. http://www. cocopeat.com.au/technical/productA nalysis/pdf/C resswelldoc.pdf, accessed 6 February 2012.

De K anel, J., and Smith, R. 1992. Cultivation of Nepenthes at L ongwood Gardens: A n update after 12 years. Carniv. PI. Newslett. 21(4): 101-105.

Greer, L. 1998. Organic potting mixes. http://www.cannabase.com/cl/bcga/soil/potmix.html, accessed 6 February 2012.

Harris Laboratories. 2009. M anaging saline $\&$ alkaline soil: soil diagnosis. http://documents.crinet.com/A gSource-Cooperative-Services/L ocations/SalineAlkaSoils.pdf, accessed 6 February 2012.

Hernández-A paolaza, T., Gascó, A .M ., Gascó, J.M., and Guerrero, F. 2005. Reuse of waste materials as growing media for ornamental plants. Bioresour. Technol. 96(1): 125-131.

Horman, S. R. 2000. Propagation of pitcher plantl ets from seed. http://www. pitcherplant.org/propagation.html, accessed 30 A pril 2004.

Holcomb, E.J. 2004. Growing media. Unpublished Greenhouse M anagement class notes, College A gric. Sci., Penn. State Univ. 8 p.

Ingelmo, F., Canet, R., I bañez, M., Pomares, F., and Garcia, J. 1998. U se of M SW compost, dried sewage sludge and other wastes as partial substitutes for peat and soil. Bioresour. Technol. 63(2): 123-129. 
Lennartson, M . 1997. The peat conservation issue and the need for alternatives. In: Proceedings of IPS International Peat Conference on Peat Horticulture. Schmilewski. A msterdam. pp. 112-121 (as cited in Hernández-A paolaza et al.).

M acfarlane, J. 1911. Nepenthes truncata M acf. Trans. \& Proc. Bot. Soc. Pennsylvania. ii. 209.

[M AFF] M inistry Of A griculture, Fisheries and Food. 2001. Importance of aeration in container medium. N ursery production Factsheet. http://www.agf.gov.bc.ca/ornamentals/floriculture/aeration.pdf, accessed 6 February 2012.

M alesiana Tropicals. n.d.. M alesiana tropicals. http://www.malesiana.com, accessed 8 October 2004.

M arianthi, T. 2006. Kenaf (Hibiscus cannabinus L .) core and rice husks as components of container media for growing P inus halepensis M. seedlings. B ioresour. Technol. 97(14): 1631-1639.

M auseth, J.D. 1998. B otany. A n Introduction to Plant Biology. J ones and B artlett Publishers, Inc., USA. pp. 144-376.

M cPherson, S.R., and A moroso, V.B. 2011. Field Guide to the Pitcher Plants of the Philippines. Redfern Natural History Productions, Poole.

[NGIA ]. Nursery and Garden Industry Australia. 2002. Water-retention efficiency of potting mixes. The Nursery Papers. ISSN: 1326-1495. Issue Number: 2002/7. http://www.ngia.com. au/Folder?A ction=Download\&Folder_id=105\&File=NP_2002_07.pdf, accessed 6 February 2012.

Noguera,P., A bad, M., N oguera, V., Puchades, R., and M aquierira, A. 2000. Coconut coir waste, a new and viable ecologically-friendly peat substitute. A cta Horticult. (ISHS) 517: 279-286 (as cited in Hernández-A paolaza et al.).

Polunin, I. 1994. Plant and Flowers of M alaysia. Times Editions Pte. L td., Singapore. 94-130.

Premier Press. 2000. Disease suppression associated with sphagnum peat moss. Premier Press. Summer 2000, vol. 7, no. 2.

Raviv, M., Chen, Y., and Inbar, Y. 1986. Peat and peat substitutes as growth media for containergrown plants. In Y. Chen and Y. Avnimelech, eds. Developments in Plant and Soil Sciences: The Role of Organic M atter in M odern A griculture. M artinus Nijhoff Publisher, Dordrech. pp. 257-287.

Rice, B.A. 2006. Growing Carnivorous Plants. Timber Press Inc., USA . 126p.

Sarracenia Northwest. 2012. Nepenthes - A sian pitcher plant. http://www.cobraplant.com/index. php?main_page=page\& id=32, accessed 6 February 2012.

Schwegman, J. 1996. Plant species biology summary for Tennessee M ilk Vetch. Illinois Department of Natural Resources. Division of Natural Heritage. http://dnr.state.il.us/conservation/naturalheritage/botany/htmlastr.htm, accessed 6 February 2012.

Strain, M. 1999. Soil and water-holding capacity. Lab 2 - M odeling soil water content and runoff. http://www.woodrow.org/teachers/esi/1999/princeton/projects/modeling/lab2app_c.html, accessed 6 February 2012.

Vogelpoel, L. 1980. Disa uniflora - Its propagation and cultivation. A mer. Orchid Soc. Bull. 49: 961-972.

Wilson, S.B., and Stoffella, P.J. 2000. 258 Organic media alternatives to peat for container-grown tropical perennial production. HortScience 35(3): 435-436. 